\title{
Pengaruh Perputaran Kas, Modal Kerja dan Rasio Lancar terhadap Profitabilitas Pada Perusahaan Manufaktur yang Terdaftar di Bursa Efek Indonesia pada Tahun 2015-2017
}

\author{
Elsa Reina Nainggolan \\ Universitas Prima Indonesia \\ elsanainggolan1198@gmail.com
}

Yul Franica Astri Sitompul

Universitas Prima Indonesia

yastrisitompu188@gmail.com

\author{
Marisa Anindita Saragih \\ Universitas Prima Indonesia \\ marisaanindita6@gmail.com
}

Jholant Bringg Luck Amelia Br Sinaga

Universitas Prima Indonesia

jho.amelia@gmail.com

Corresponding Author : Elsa Reina Nainggolan

Submitted: 30 Juni 2020

Accepted: 03 Agustus 2020

Published: 03 Agustus 2020

ABSTRAK

Situasi ekonomi di Indonesia detik ini mampu dianalisis dari banyaknya industri yang tumbuh dan terus berkembang salah satunya pada industri Manufaktur. Sampel yang diperoleh pada pengamatan ini sebanyak 74 sampel perusahaan dengan hasil observasi selama 3 tahun yakni pada tahun 2015 - 2017, sehingga data observasi diperoleh sebanyak 222 sampel. Penelitian ini menggunakan data sekunder melalui teknik purposive sampling. Metode yang digunakan metode analisis regresi linear berganda. Hasil dari riset ini menyatakan bahwa secara keseluruhan perputaran kas, perputaran modal kerja, dan rasio lancar berpengaruh secara signifikan terhadap profitabilitas. Secara parsial, variabel perputaran kas, perputaran modal kerja tidak berpengaruh terhadap profitabilitas. Dan variabel rasio lancar berpengaruh dan signifikan terhadap profitabilitas.

Keywords: Perputaran Kas, Perputaran Modal Kerja, Rasio Lancar dan Profitabilitas

\section{PENDAHULUAN}

\subsection{Latar Belakang Masalah}

Perusahaan manufaktur salah satu industri yang menggarap bahan belum jadi menjadi barang jadi siap dijual. Perusahaan manufaktur berpengaruh besar pada perkembangan ekonomi Indonesia. Kas berpengaruh terhadap perkembangan sektor industri kedepannya. Jika dilihat dari sisi pemilik, perusahaan yang memiliki kas yang cukup banyak dapat digolongkan sebagai perusahaan yang baik. Dengan adanya modal kerja, suatu industri mampu menggunakannya sebagai dana untuk memenuhi kebutuhan bersifat lancar serta 
kegiatan operasional perusahaan. Dalam perhitungannya, modal kerja yang bagus mampu menarik investor untuk berinvestasi.

Rasio Lancar berfungsi membantu pengambilan keputusan disuatu industri. Rasio lancar yang tinggi menunjukkan bahwa banyaknya sisa kas perusahaan yang tidak digunakan secara efektif. Laba menjadi tolak ukur bahwa perusahaan tersebut dalam kondisi baik atau tidak. Jika industri mempunyai profit yang tinggi maka investor bisa menanam modal pada perusahaan tersebut.

Berdasarkan fenomena pada PT. Kino Indonesia Tbk. Tahun 2015 memiliki ratarata kas sebesar Rp355.170.899.351 dan memperoleh laba sebesar Rp263.031.112.748. Pada tahun 2016 jumlah rata-rata kas mengalami kenaikan sebesar 46,78\% dimana dimiliki rata-rata kas sebesar Rp521.321.773.355 namun kenaikan jumlah rata-rata kas ini tidak diikuti dengan laba mengalami penurunan sebesar 31,145\%, dimana laba menjadi Rp181.110.153.810. (Bursa Efek, 2018)

Pada PT. Wilmar Cahaya Indonesia Tbk, dapat dilihat bahwa tahun 2016 jumlah penjualan bersih sebesar Rp4.115.541.761.173 dan laba sebesar Rp249.697.013.626. Dan pada tahun 2017 jumlah penjualan bersih mengalami peningkatan sebesar $3,46 \%$ dimana dimiliki penjualan bersih sebesar Rp4.257.738.486.908, kenaikan penjualan bersih ini tidak diikuti dengan kenaikan laba sebesar 56,98\% dimana diperoleh laba sebesar Rp107.420.886.839. (Bursa Efek, 2018)

Pada PT. Jembo Cable Company Tbk, dapat dilihat bahwa tahun 2015 dimiliki hutang lancar sebesar Rp883.284.008.000 dan laba sebesar Rp2.464.669.000. Pada tahun 2016, jumlah hutang lancar mengalami kenaikan sebesar $12,37 \%$ dimana hutang lancar $\mathrm{Rp}$ 992.544.784.000, namun jumlah hutang lancar yang mengalami kenaikan diikuti dengan laba yang diperoleh 5.272,86\%,dimana laba sebesar $\mathrm{Rp}$ 132.423.161.000. (Bursa Efek, 2018)

\section{LANDASAN TEORI}

2.1. Teori Pengaruh Perputaran Kas Terhadap Profitabilitas

Menurut Rahma (Amaral Canizio, 2017), "Perputaran kas menunjukkan kemampuan menghasilkan pendapatan, sehingga diketahui berapa kali berputar dalam satu periode."

Menurut Kasmir (Nuriyani \& Zannati, 2017). "Perputaran kas berguna mengukur tingkat kecukupan modal kerja perusahaan yang diperlukan guna membayar tagihan."

Perputaran kas memiliki pengaruh positif yang artinya peningkatan pada perputaran kas akan diikuti peningkatan laba. (Wirasari \& Sari, 2016)

Menurut Riyanto (Arianti, 2018), indikator perputaran kas :

$$
\text { Perputaran Kas }=\frac{\text { Penjualan }}{\text { Rata }- \text { Rata Kas }}
$$

\subsection{Teori Pengaruh Perputaran Modal Kerja Terhadap Profitabilitas}

Menurut Kasmir (Maming, 2019). "Perputaran modal kerja adalah rasio yang berguna mengukur keefektifan modal kerja perusahaan."

Menurut Ambarwati (Putri, Apritika Dwi, 2020). "Modal kerja adalah modal yang berguna sehingga perusahaan dapat melakukan operasional dengan lancar dan mencapai tujuan akhir yaitu menghasilkan laba."

Menurut Munawir (Satriya \& Lestari, 2014). "Perputaran modal kerja menunjukkan relevansi antara penjualan dengan modal kerja."

Menurut Fahmi (Parlina, 2017) indikator yang digunakan : 
Perputaran Modal Kerja =

$$
\text { Modal Kerja }
$$

\subsection{Teori Pengaruh Rasio Lancar Terhadap Profitabilitas}

Menurut Afriyanti (PA \& Marbun, 2016), "Rasio Lancar berpengaruh negatif terhadap Return on Assets."

Menurut Fahmi (Mesrawati et al., 2020), “ Perusahaan yang memiliki rasio lancar yang tinggi dianggap baik, bahkan bagi para kreditur dalam keadaan kuat.“

Menurut Hery (Khoirunnisa, 2017), "Rasio lancar berfungsi menaksir kesanggupan suatu industri dalam menyanggupi liabilitas jangka pendek."

Menurut (Kasmir (2015:10), indikator rasio lancar:

$$
\text { Rasio Lancar }=\frac{\text { Aktiva Lancar }}{\text { Hutang Lancar }}
$$

\subsection{Kerangka Konseptual}

Berdasarkan penjelasan diatas, maka kerangka konseptualnya ialah :

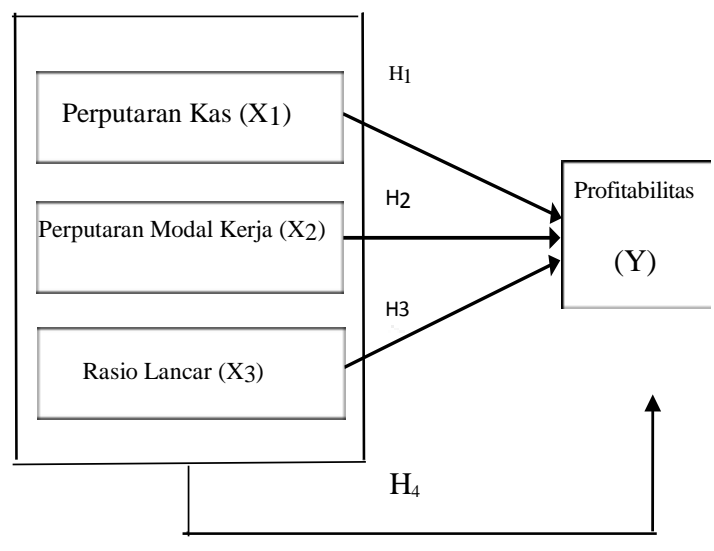

Gambar 2.1 Kerangka Konseptual

\section{5 Hipotesis Penelitian}

Hipotesis masalah yang digunakan ialah:

$\mathrm{H}_{1}$ :Perputaran kas berpengaruh secara parsial terhadap profitabilitas. $\mathrm{H}_{2}$ :Perputaran modal kerja berpengaruh secara parsial terhadap profitabilitas.

$\mathrm{H}_{3}$ :Rasio lancar berpengaruh secara parsial terhadap profitabilitas.

$\mathrm{H}_{4}$ :Perputaran kas, perputaran modal kerja serta rasio lancar berpengaruh secara simultan terhadap profitabilitas.

\section{METODOLOGI PENELITIAN 3.1.Pendekatan Penelitian}

Menurut (Sugiyono, 2015), penelitian yang bersifat kuantitatif dianggap selaku metode observasi yang berlandaskan pada filsafat positif dipergunakan untuk mengobservasi populasi atau sampel terpilih.

\subsection{Populasi dan Sampel}

Sampel diambil dengan menggunakan metode purposive sampling. Sampel dalam penulisan ini

\begin{tabular}{|c|c|c|}
\hline NO & Kriteria Sampel & $\begin{array}{l}\text { Jumlah } \\
\text { Sampel }\end{array}$ \\
\hline 1 & $\begin{array}{c}\text { Perusahaan manufaktur } \\
\text { yang terdaftar pada tahun } \\
2015-2017\end{array}$ & 146 \\
\hline 2 & $\begin{array}{l}\text { Perusahaan manufaktur } \\
\text { yang tidak melaporkan } \\
\text { laporan keuangan berturut } \\
\text { tahun 2015-2017 }\end{array}$ & (26) \\
\hline 3 & $\begin{array}{l}\text { Perusahaan manufaktur } \\
\text { yang mengalami kerugian } \\
\text { tahun } 2015-2017\end{array}$ & (46) \\
\hline & Total Sampel & 74 \\
\hline & $\begin{array}{c}\text { Observasi pengamatan } \\
(74 \times 3 \text { tahun })\end{array}$ & 222 \\
\hline
\end{tabular}
dipilih berdasarkan kriteria berikut:

Tabel 3.1 Kriteria Sampel Penelitian

\subsection{Uji Asumsi Klasik Uji Normalitas}


Menurut (Ghozali, 2016), menyatakan uji normalitas mempunyai guna mengukur apakah variabel penggangu atau residual berdistribusi normal.

\section{Uji Multikolienieritas}

Menurut (Ghozali, 2016), menyatakan, uji multikolinieritas berfungsi mengevaluasi apakah model regresi mempunyai hubungan antar variabel independen. Model regresi sebaiknya tidak terjadi korelasi.

\section{Uji Autokolerasi}

Menurut (Ghozali, 2016), uji ini bertujuan menguji apakah terdapat hubungan antara kesalahan pengganggu pada periode $t$ dengan kesalahan pengganggu pada periode $\mathrm{t}-1$ (sebelumnya). Jika terdapat korelasi, maka adanya masalah autokorelasi.

\section{Uji Heteroskedastisitas}

Menurut (Ghozali, 2016), uji heteroskedastisitas berfungsi dalam menguji regresi untuk memastikan terjadi ketidaksamaan variance dari satu pengamatan terhadap pengamatan yang lain. Apabila asumsi variance dari residual satu pengamatan ke lainnya tidak terpenuhi, dinyatakan bahwa variance tidak valid atau dinamakan Homoskedastisitas dan jika variance dari seluruh pengamatan berbeda disebut Heteroskedastisitas.

\subsection{Model Analisis Penelitian}

Model penelitian yang berfungsi menggunakan analisis regresi linear berganda. Menurut teori (Ghozali, 2016), model pengamatan data regresi berganda berfungsi untuk mengetahui besarnya korelasi dan pengaruh variabel independen yang jumlahnya dua atau lebih $\left(\mathrm{X}_{1}, \mathrm{X}_{2}, \mathrm{X}_{3}\right)$, terhadap variabel dependen (Y). Model regresi linear berganda yang digunakan :

$$
\mathrm{Y}=\mathrm{a}+\mathrm{b}_{1} \mathrm{X}_{1}+\mathrm{b}_{2} \mathrm{X}_{2}-\mathrm{b}_{3} \mathrm{X}_{3}+\mathrm{e}
$$

\section{Uji Koefisien Determinasi (Adjusted $\boldsymbol{R}^{\mathbf{2}}$ )}

Menurut (Ghozali, 2016), koefisien determinasi (adjusted $R^{2}$ ) yang berfungsi mengetahui kapabilitas model dalam menjelaskan varian variabel terikat. Nilai koefisien determinasi antara nol dan satu..

Uji Signifikan secara Simultan (Uji-F)

Menurut (Ghozali, 2016), uji F berguna menunjukkan variabel independen atau bebas mempunyai pengaruh secara bersama-sama terhadap variabel dependen. Adapun kriteria:

1. Jika $F_{\text {hitung }}<\mathrm{F}_{\text {tabeluntuk } \alpha}=5 \%$ maka $\mathrm{H}_{0}$ diterima dan $\mathrm{H}_{\mathrm{a}}$ ditolak

2. Jika $F_{\text {hitung }}>F_{\text {tabeluntuk } \alpha}=5 \%$ maka $\mathrm{H}_{0}$ ditolak dan $\mathrm{H}_{\mathrm{a}}$ diterima

\section{Uji Signifikan Secara Parsial (Uji-t)}

Menurut (Ghozali, 2016), uji-t normalnya menunjukkan pengaruh variabel independen. Uji t yang digunakan adalah untuk membandingkan nilai signifikan $\mathrm{t}$ dengan $\alpha=0,05$. Adapun kriteria pengambilan keputusan adalah:

1. Jika $\mathrm{t}_{\text {hitung }}<\mathrm{t}_{\text {tabel }}$ untuk $\alpha=5 \%$ maka $\mathrm{H} 0$ diterima dan HA ditolak

2. Jika $t_{\text {hitung }}>t_{\text {tabel }}$ atau $-t_{\text {hitung }}<-t_{\text {tabel }}$ untuk $\alpha=5 \%$ maka $\mathrm{H} 0$ ditolak dan HA diterima

\section{HASIL DAN PEMBAHASAN}

4.1 Hasil Penelitian

\subsubsection{Statistik Deskriptif}

Berdasarkan data-data dari seluruh variabel independen pada survery ini maka dibuat statistik deskriptif : 
Tabel 4.1. Statistik Deskriptif

\begin{tabular}{|l|l|l|l|l|l|}
\hline \multicolumn{6}{|l|}{ Descriptive Statistics } \\
\hline & N & Min & Max & Mean & Std. Dev. \\
\hline P_kas & 222 &, 8842 & 365,6530 & 29,725595 & $\begin{array}{l}46,234929 \\
4\end{array}$ \\
\hline $\begin{array}{l}\text { P_Moda } \\
\text { lKerja }\end{array}$ & 222 & $\begin{array}{l}- \\
386,45 \\
82\end{array}$ & 1893,9530 & 24,652627 & $\begin{array}{l}174,62528 \\
73\end{array}$ \\
\hline $\begin{array}{l}\text { Current_ } \\
\text { Ratio }\end{array}$ & 222 &, 5842 & 15,1646 & 2,518064 & 2,0071132 \\
\hline ROI & 222 &, 0002 &, 5267 &, 073872 &, 0790493 \\
\hline $\begin{array}{l}\text { Valid N } \\
\text { listwise) }\end{array}$ & 222 & & & & \\
\hline
\end{tabular}

\subsection{Hasil Uji Asumsi Klasik \\ 4.2.1 Uji Normalitas Analisis Grafik}

Pengujian ini berwujud menganalisa pengaruh regresi variabel penggangu alias residual menyandangsirkulasinormal.

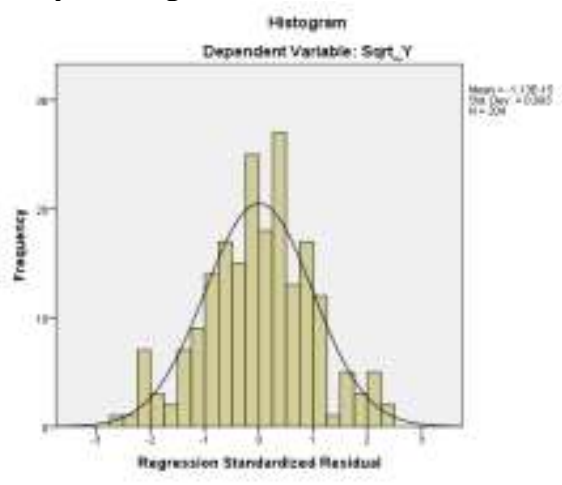

Gambar 4.1 Normalitas Grafik Histogram

Setelah melihat gambar 4.1, manifestasi grafik data yang sudah ditransformasi, menjelaskan bahwa informasi sudah bersirkulasi normal.

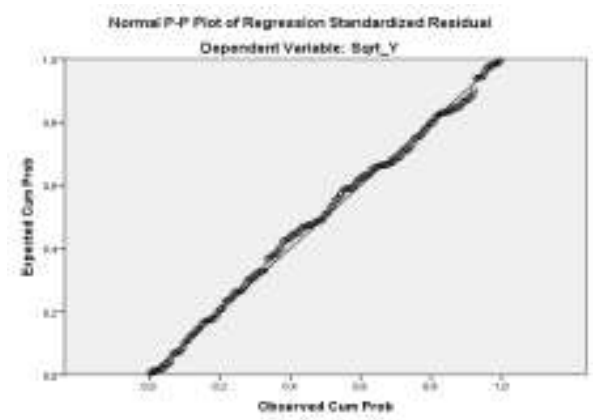

Gambar 4.2 Normalitas Probability Plot
Berdasarkan tampilan pada gambar 4.2, dapat diamati dari grafik normal probability plot sudah menunjukkan penyebaran yang melintasi garis lurus diagonal.

\section{Analisis Statistik}

Tabel 4.2. Hasil Uji KolmogorofSmirnov

\begin{tabular}{|c|c|c|}
\hline \multicolumn{3}{|l|}{$\begin{array}{l}\text { One-Sample } \\
\text { Test }\end{array}$} \\
\hline & & $\begin{array}{l}\text { Unstandardize } \\
\text { d Residual }\end{array}$ \\
\hline \multicolumn{2}{|l|}{$\mathrm{N}$} & 204 \\
\hline \multirow{2}{*}{$\begin{array}{l}\text { Normal } \\
\text { Parameters }{ }^{\mathrm{a}} \text {, } \\
\text { b }\end{array}$} & Mean &, 0000000 \\
\hline & $\begin{array}{l}\text { Std. } \\
\text { Deviatio } \\
\mathrm{n}\end{array}$ & ,09980098 \\
\hline \multirow{3}{*}{\begin{tabular}{|l} 
Most \\
Extreme \\
Differences
\end{tabular}} & Absolute &, 044 \\
\hline & Positive &, 036 \\
\hline & Negative &,- 044 \\
\hline \multicolumn{2}{|c|}{$\begin{array}{l}\text { Kolmogorov-Smirnov } \\
\mathrm{Z}\end{array}$} &, 625 \\
\hline \multicolumn{2}{|c|}{ Asymp. Sig. (2-tailed) } &, 829 \\
\hline \multicolumn{3}{|c|}{ a. Test distribution is Normal. } \\
\hline
\end{tabular}

Sumber : Pengolahan Statistik SPSS, 2019

Pada tabel 4.2, hasil uji Kolmogorov-Smirnov (Uji K-S) setelah transformasi adalah sebesar 0,625 dan nilai signifikan adalah 0,829 dengan nilai probabilitas 0,05 $(0,829>0,05)$. Dari hasil data tersebut dapat disimpulkan $\mathrm{H} 0$ diterima dan HA ditolak yaitu residual data berdistribusi normal.

\subsubsection{Uji Multikolinieritas}

Multikorelasi bisa diamati dari (1) angka tolerance dan lawannya (2) variance inflation factor (VIF). 
Tabel 4.3. Hasil Uji Multikolinieritas

\begin{tabular}{|l|l|l|l|}
\hline \multicolumn{2}{|l|}{ Model } & \multicolumn{2}{l|}{$\begin{array}{l}\text { Collinearity } \\
\text { Statistics }\end{array}$} \\
\cline { 3 - 4 } \multicolumn{2}{|l}{} & $\begin{array}{l}\text { Toleran } \\
\text { ce }\end{array}$ & VIF \\
\hline \multirow{2}{*}{1} & (Const.) & & \\
\cline { 2 - 4 } & Sqrt_x1 &, 928 & 1,078 \\
\cline { 2 - 4 } & Sqrt_x2 &, 890 & 1,123 \\
\cline { 2 - 4 } & Sqrt_x3 &, 838 & 1,194 \\
\hline
\end{tabular}

Menurut tabel 4.3, pengamatan itu memberikan simpulan bahwa data tetap berdistribusi normal.

\subsubsection{Uji Autokorelasi}

Pengujian ini untuk mengetahui apakah adanya koneksi antara kesalahan pengganggu di periode tahun $t$ dengan periode tahun yang lalu

Tabel 4.4. Hasil Uji Autokorelasi

\begin{tabular}{|l|l|l|l|l|r|}
\hline Model & & $\mathrm{R}$ & $\begin{array}{c}\text { Adjusted } \\
\mathrm{R} \\
\text { Square }\end{array}$ & $\begin{array}{c}\text { Std. } \\
\text { Error of } \\
\text { the } \\
\text { Estimate }\end{array}$ & $\begin{array}{c}\text { Durbin- } \\
\text { Watson }\end{array}$ \\
\hline 1 &, $433^{\mathrm{a}}$ &, 187 &, 175 &, 10055 & 1,859 \\
\hline Square & \\
a. Predictors: (Constant), Sqrt_x3, Sqrt_x1, Sqrt_x2 \\
\hline
\end{tabular}

Berdasarkan tabel 4.4, dapat dilihat hasil uji DW sebanyak 1,859, angka ini dapat dibandingkan dengan nilai tabel yang telah diuji memakai nilai signifikan 5\% dengan jumlah sampel (n) 222 dan jumlah variabel independen $3(\mathrm{k}=3)$. Dari tabel DW diperoleh nilai du (batas atas) sebanyak 1,79753. Kriteria untuk terbebas dari autokorelasi sehat atau deskruktif adalah $\mathrm{du}<\mathrm{d}<4-\mathrm{du}$. Dalam penelitian ini nilai DW 1,806 memiliki nilai lebih besar dari nilai du 1,9753 . Hasil pengujian ini adalah $1,79753 \leq 1,859<2,20247$. Maka, model tersebut tidak terjadi autokorelasi sehat atau deskruktif.

\subsubsection{Uji Heterokedastisitas}

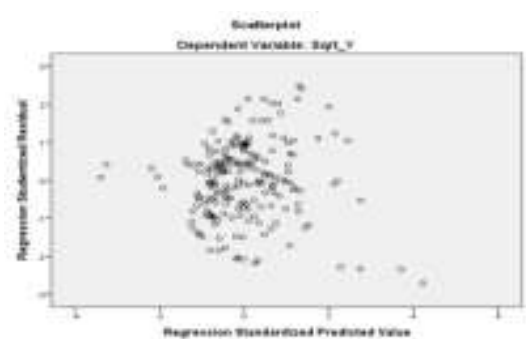

Gambar 4.3 Grafik Scatterplot

Berdasarkan gambar 4.3 grafik dari gambar grafik scatterplot sesudah ransformasi bisa dilihat bahwa penyebaran titik secara acak dan menyeluruh. Maka tidak terjadi heteroskedastisitas pada model regresi.

Tabel 4.5. Hasil Uji Park

\begin{tabular}{|c|c|c|c|c|c|c|}
\hline \multicolumn{7}{|c|}{ Coefficients $^{\mathrm{a}}$} \\
\hline \multirow{2}{*}{\multicolumn{2}{|c|}{ Model }} & \multicolumn{2}{|c|}{$\begin{array}{l}\text { Unstandardized } \\
\text { Coefficients }\end{array}$} & \multirow{2}{*}{$\begin{array}{l}\begin{array}{c}\text { Stand. } \\
\text { Coef. }\end{array} \\
\text { Beta }\end{array}$} & \multirow[b]{2}{*}{$\mathrm{t}$} & \multirow[b]{2}{*}{ Sig. } \\
\hline & & B & $\begin{array}{l}\text { Std. } \\
\text { Error }\end{array}$ & & & \\
\hline \multirow[t]{4}{*}{1} & (Constant) & $-7,117$ & ,288 & & $-24,681$ & 000 \\
\hline & P_Kas &,- 003 &, 003 &,- 052 &,- 768 & ,443 \\
\hline & P_ModalKerja &,- 001 &, 001 &,- 052 &,- 766 & 445 \\
\hline & Rasio Lancar & .070 & .080 & .060 & .879 & 380 \\
\hline \multicolumn{7}{|c|}{ a. Dependent Variable: LNU_RES1 } \\
\hline
\end{tabular}

Menurut tabel 4.5 uji park dapat dilihat bahwa probabilitas atau taraf signifikansi variabel perputaran kas sejumlah 0,443 , perputaran modal kerja sejumlah 0,445 , dan rasio lancar sejumlah 0,380 . Berdasarkan data, semua variabel bebas memiliki nilai sig $>0,05$, sehingga model regresi dikatakan tidak mengalami heteroskedastisitas.

\subsection{Hasil Analisis Data Penelitian} 4.3.1 Model Penelitian

Tabel 4.6. Regresi Linier Berganda Coefficients $^{\mathrm{a}}$

\begin{tabular}{|c|c|c|c|c|c|c|}
\hline \multirow{2}{*}{\multicolumn{2}{|c|}{ Model }} & \multicolumn{2}{|c|}{$\begin{array}{c}\text { Unstandardized } \\
\text { Coefficients }\end{array}$} & \multirow{2}{*}{$\begin{array}{c}\begin{array}{c}\text { Standardized } \\
\text { Coefficients }\end{array} \\
\text { Beta } \\
\end{array}$} & \multirow[b]{2}{*}{$\mathrm{T}$} & \multirow[b]{2}{*}{ Sig. } \\
\hline & & B & $\begin{array}{l}\text { Std. } \\
\text { Error }\end{array}$ & & & \\
\hline \multirow[t]{4}{*}{1} & (Constant) & , 109 &, 031 & & 3,529 & ,001 \\
\hline & Sqrt_x1 & ,001 & ,002 & ,040 & ,603 & ,547 \\
\hline & Sqrt_x2 &,- 003 & ,002 &,- 127 & $\begin{array}{r}- \\
1,881 \\
\end{array}$ & ,061 \\
\hline & Sqrt_x3 & ,084 &, 015 & ,383 & 5,504 & ,000 \\
\hline
\end{tabular}


Dapat ditinjau dari tabel 4.6 maka ditemukannya persamaan linier berganda hipotesis penelitian yakni :

\section{Profitabilitas $=0,109+0,001 X_{1}-$ $0,003 X_{2}+0,084 X_{3}$}

Berlandaskan persamaan regresi diketahui bahwa:

1. Terdapat nilai konstanta sejumlah 0,109 . Maksudnya ialah variabel independen dianggap konstan, maka profitabilitas mengalami kenaikan sejumlah 0,109 .

2. Angka koefisien regresi variabel perputaran kas sejumlah 0,001 . Maksudnya apabila terjadi peningkatan 1 satuan perputaran kas akan mengakibatkan kenaikan profitabilitas sejumlah $0,1 \%$ dengan premis variabel lainnya konstan.

3. Nilai koefisien variabel perputaran modal kerja sejumlah $-0,003$. Berarti bahwa apabila adanya penurunan 1 satuan perputaran modal kerja mengakibatkan penurunan risiko sistematis sebesar $0,3 \%$ terhadap premis variabel lainnya konstan.

4. Nilai koefisien variabel rasio lancar sebesar 0,084. Ini menyatakan setiap kenaikan 1 satuan rasio lancar mampu mengakibatkan kenaikan risiko tertata sebesar $8,4 \%$ dengan premis variabel lainnya konstan.

\subsubsection{Koefisien Determinasi $\left(R^{2)}\right.$}

Tabel 4.7. Hasil Koefisien Determinasi Model Summary ${ }^{\mathrm{b}}$

\begin{tabular}{|c|c|c|c|c|}
\hline Model & $\mathrm{R}$ & $\begin{array}{c}\mathrm{R} \\
\text { Square }\end{array}$ & $\begin{array}{l}\text { Adjusted } \\
\text { R Square }\end{array}$ & $\begin{array}{l}\text { Std. Error } \\
\text { of the } \\
\text { Estimate }\end{array}$ \\
\hline 1 &, $433^{\mathrm{a}}$ &, 187 & 175 & ,10055 \\
\hline \multicolumn{5}{|c|}{$\begin{array}{l}\text { a. Predictors: (Constant), Sqrt_x3, Sqrt_x1, } \\
\text { Sqrt_x2 }\end{array}$} \\
\hline
\end{tabular}

Pada Tabel 4.7, pengaruh ketiga variabel bebas terhadap variabel terikat dinyatakan dengan nilai ataupun angka adjusted $R$ square yaitu sebanyak 0,175 atau $17,5 \%$.

\subsubsection{Pengujian Hipotesis Secara Parsial (Uji t)}

Tabel 4.8. Hasil Uji t

Coefficients $^{\mathrm{a}}$

\begin{tabular}{|c|c|c|c|c|c|}
\hline \multirow[t]{2}{*}{ Model } & \multicolumn{2}{|c|}{$\begin{array}{c}\text { Unstandardized } \\
\text { Coefficients }\end{array}$} & \multirow{2}{*}{$\begin{array}{c}\begin{array}{c}\text { Standardized } \\
\text { Coefficients }\end{array} \\
\text { Beta }\end{array}$} & \multirow[b]{2}{*}{$\mathrm{T}$} & \multirow[b]{2}{*}{ Sig. } \\
\hline & B & $\begin{array}{l}\text { Std. } \\
\text { Error }\end{array}$ & & & \\
\hline 1 (Constant) & ,109 & ,031 & & 3,529 &, 001 \\
\hline Sqrt $x 1$ & 001 & 002 & ,040 & 603 & .547 \\
\hline Sqrt_x2 &,- 003 & ,002 &,- 127 & 1,881 & 061 \\
\hline Sqrt_x3 & 084 & 015 & ,383 & 5,504 & ,000 \\
\hline
\end{tabular}

a. Dependent Variable: Sqrt_Y

Dalam survey ini, nilai t tabel ialah sebesar 2.25699. Berikut hasil uji parsial yaitu:

a. Variabel perputaran kas memiliki nilai $\mathrm{t}$ hitung 0.603 dimana nilai $\mathrm{t}$ tabel sebesar2.25699. Maka dapat dilihat bahwa $\mathrm{t}$ hitung $<\mathrm{t}$ tabel dengan tingkat signifikan $0,547>0.05$, maka dengan demikian dapat disimpulkan $\mathrm{HO}$ diterima dan HA ditolak yang artinya variabel perputaran kas tidak berpengaruh.

b. Variabel perputaran modal kerja memiliki nilai t hitung $-1.881<\mathrm{t}$ tabel 2.25699 dengan tingkat signifikansi berada pada perbandingan $0,000<$ 0.05 , maka ditarik kesimpulan bahwa H0 ditolak dan HA diterima maksudnya variabel perputaran modal kerja berpengaruh negatif dan signifikan terhadap profitabilitas.

c. Variabel rasio lancar memiliki nilai $t$ hitung $5.504>\mathrm{t}$ tabel 2.25699 dengan tingkat signifikansi berada pada perbandingan $0.000<0.05$. maka dapat disimpulkan $\mathrm{H} 0$ ditolak dan HA diterima artiny a variabel rasio lancar memiliki pengaruh positif dan signifikan terhadap profitabilitas.

\subsubsection{Pengujian Hipotesis Secara Simultan (UjiF)}

Tabel 4.9. Hasil Uji F 


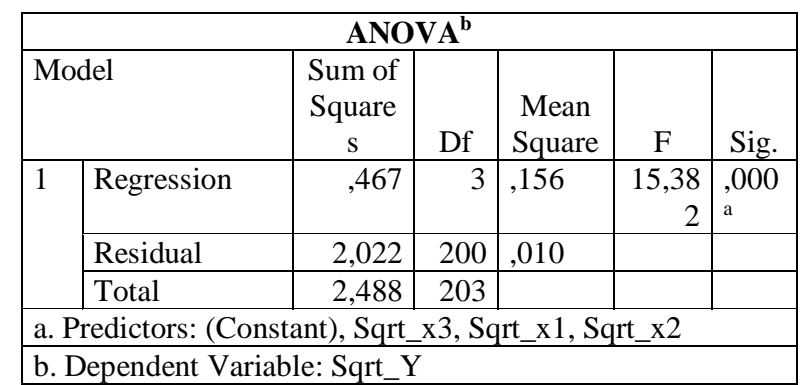

Pada Tabel 4.9, nilai $\mathrm{F}$ hitung adalah 15,382 dengan tingkat signifikansi sebesar $0,000<0,05$. Nilai ini bisa ditolok dengan $\mathrm{F}$ tabel yang ada di tingkat kepercayaan $95 \%$. Dilihat pada Tabel $\mathrm{F}$ untuk $\alpha=0,05$ diperoleh $\mathrm{F}$ tabel $=2.65$. Sebab nilai $\mathrm{F}$ hitung $>\mathrm{F}$ tabel dengan tingkat signifikansi lebih rendah atau sedikit dari 0,05 , ini memberitahu bahwa variabel bebas secara simultan berpengaruh signifikan terhadap profitabilitas. Perhitungan menyimpulkan bahwa H0 ditolak dan HA diterima.

\subsection{Pembahasan Hasil \\ 4.4.1 Pengaruh Perputaran Kas Terhadap Profitabilitas}

Berdasarkan hasil pengujian hipotesis secara parsial pada variabel perputaran kas diperoleh bahwa variabel perputaran kas tidak berpengaruh terhadap profitabilitas pada perusahaan manufaktur yang terdaftar di Bursa Efek periode 2015-2017. Hal ini dapat dilihat dimana hasil pengujian $t$ hitung 0.603 dimana nilai $\mathrm{t}$ tabel sebesar 2.25699. Maka dapat dilihat bahwa t hitung $<\mathrm{t}$ tabel dengan tingkat signifikan $0,547>0.05$, maka dengan demikian dapat disimpulkan H0 diterima dan HA ditolak yang artinya variabel perputaran kas tidak berpengaruh.

Penelitian ini tidak sejalan dengan teori yang dikemukakan oleh (Nuriyani \& Zannati, 2017), yang mengatakan bahwa rasio perputaran kas memiliki pengaruh yang signifikan terhadap profitabilitas.

\subsubsection{Pengaruh Modal Kerja Terhadap Profitabilitas}

Berdasarkan hasil pengujian hipotesis secara parsial pada variabel perputaran modal kerja tidak berpengaruh. Hal ini dapat dilihat dimana hasil pengujian $\mathrm{t}$ hitung $-1.881<\mathrm{t}$ tabel 2.25699 dengan tingkat signifikansi berada pada perbandingan $0,061>0.05$, maka ditarik kesimpulan bahwa $\mathrm{H} 0$ diterima dan HA ditolak maksudnya variabel perputaran modal kerja tidak berpengaruh.

Penelitian ini memperkuat penelitian yang dilakukan oleh (Angelita, 2019), yang mengatakan bahwa perputaran modal kerja memiliki pengaruh positif dan tidak signifikan terhadap profitabilitas.

\subsubsection{Pengaruh Perputaran Rasio Lancar Terhadap Profitabilitas}

Berdasarkan hasil pengujian hipotesis secara parsial pada variabel rasio lancar berpengaruh. Hal ini dapat dilihat dimana hasil nilai t hitung 5.504 > t tabel 2.25699 dengan tingkat signifikansi berada pada perbandingan $0.000<0.05$, maka dapat disimpulkan $\mathrm{H} 0$ ditolak dan HA diterima artinya variabel rasio lancar memiliki pengaruh positif dan signifikan terhadap profitabilitas.

Penelitian ini sejalan dengan teori yang dikemukakan oleh (Mesrawati et al., 2020), yang mengatakan bahwa rasio berpengaruh positif dan signifikan terhadap profitabilitas. Semakin besar rasio lancar maka profitabilitas perusahaan semakin besar pula.

\section{KESIMPULAN DAN SARAN}

\subsection{KESIMPULAN}

Bersumber dari temuan yang dilakukan pada waktu riset, maka disimpulkan :

1. Berdasarkan hasil pengujian uji t, variabel perputaran kas tak ada pengaruh terhadap profitabilitas (ROI) pada perusahaan manufaktur tahun 2015-2017. 2. Berdasarkan hasil pengujian uji t, variabel perputaran modal kerja terdapat pengaruh negatif dan signifikan terhadap 
profitabilitas (ROI) pada perusahaan manufaktur tahun 2015-2017.

3. Berdasarkan hasil pengujian uji t, variabel rasio lancar terdapat pengaruh positif dan signifikan terhadap profitabilitas (ROI) pada perusahaan manufaktur tahun 2015-2017.

4. Berdasarkan penelitian ini menunjukkan bahwa secara keseluruhan variabel independen memiliki pengaruh dan signifikan terhadap profitabilitas (ROI) pada perusahaan manufaktur tahun 2015-2017.

5. Pengaruh seluruh variabel independen terhadap variabel dependen dinyatakan dengan nilai adjusted $R$ square sebanyak 0,175 atau $17,5 \%$. Dan lainnya sebesar $82,5 \%$ dijelaskan oleh faktor asing yang tidak diamati pada riset ini.

\subsection{SARAN}

1. Bagi penulis selanjutnya, diharapkan penulis mengambil variabel bebas yang berpengaruh terhadap profit perusahaan, seperti perputaran persediaan, debt to assets ratio, debt to equity ratio, maupun variabel lainnya, atau dapat menggunakan variabel bebas penelitian ini terhadap perusahaan lain selain perusahaan sektor aneka industri, atau dapat menambah periode penelitian sehingga memperluas ruang lingkup penelitian.

2. Bagi perusahaan disarankan untuk melihat dan mengevaluasi bagaimana manajemen asset lancer yang dimiliki perusahaan, terutama kas, agar asset lancar yang dimiliki mampu diinvestasikan dengan baik dan diharapkan mampu meningkatkan penjualan perusahaan yang turut meningkatkan laba yang diterima oleh industri, dimana akan menjadi pengkajian bagi para pemberi modal dalam berinvestasi, karena biasanya penyandang dana akan lebih suka melakukanpendanaan di suatu industri dengan margin yang besar.

3. Bagi para penanam modal, hasil penelitian ini dapat digunakan sebagai tolak ukur dalam melakukan pendanaan pada perusahaan manufaktur dengan melihat variabel yang mempengaruhi profitabilitas.

\section{REFERENCES}

Amaral Canizio, M. (2017). PENGARUH PERPUTARAN KAS,PERPUTARAN PIUTANG, PERPUTARAN PERSEDIAAN TERHADAP PROFITABILITAS PADA SUPERMARKET DI TIMOR LESTE. E-Jurnal Ekonomi Dan Bisnis Universitas Udayana. https://doi.org/10.24843/eeb.2017.v 06.i10.p04

Angelita, H. S. (2019). PENGARUH LEVERAGE DAN PERPUTARAN MODAL KERJA TERHADAP PROFITABILITAS PERUSAHAAN SUB SEKTOR OTOMOTIF DAN KOMPONEN YANG TERDAFTAR DI BURSA EFEK INDOENSIA TAHUN 2011-2015. 11(2), 32-42.

Arianti, R. (2018). Pengaruh Perputaran Piutang, Perputaran Kas, Perputaran Persediaan Terhadap Profitabilitas PT. Ultrajaya Milk Industri \& Trading Company, Tbk. Seminar Nasional I Universitas Pamulang, 1-21.

http://openjournal.unpam.ac.id/inde x.php/SNU/article/view/945

Bursa Efek, I. (2018). Laporan Keuangan Tahunan. Laporan Keuangan Tahunan 2014-2018.

Bursa Efek Indonesia. (2018). Indeks saham Syariah. Bursa Efek Indonesia.

Ghozali, I. (2016). Aplikasi Analisis Multivariate dengan Program IBM SPSS 23. In (Edisi 8). Semarang: Badan Penerbit Universitas 
Diponegoro.

Kasmir (2015:10). (2015). Pengertian Laporan Keuangan. Harahap (2015:105),. https://doi.org/10.1017/CBO978110 7415324.004

Khoirunnisa. (2017). Pengaruh Current Ratio dan Perputaran Modal Kerja Terhadap Profitabilitas (Return on Asset) (Survei pada Perusahaan Sub Sektor Pertambangan BatuBara yang Terdaftar di Bursa Efek Indonesia Periode 2012-2016). Universitas Nusantara PGRI Kediri, 01, 1-7. http://www.albayan.ae

Maming, R. (2019). PENGARUH PERPUTARAN MODAL KERJA TERHADAP PROFITABILITAS PADA PERUSAHAAN MANUFAKTUR YANG TERDAFTAR DI BURSA EFEK INDONESIA. Jurnal Manajemen STIE Muhammadiyah Palopo. https://doi.org/10.35906/jm001.v4i2 .279

Mesrawati, M., Tiosandy, Y., Silvia, S., Cindy, C., Rezcintami, M., \& Lonika, T. (2020). Pengaruh Rasio Lancar, Perputaran Kas dan Perputaran Persediaan terhadap Profitabilitas. Berkala Akuntansi Dan Keuangan Indonesia. https://doi.org/10.20473/baki.v5i1.1 8031

Nuriyani, N., \& Zannati, R. (2017). PENGARUH PERPUTARAN KAS DAN PERPUTARAN PIUTANG TERHADAP PROFITABILITAS PERUSAHAAN SUB-SEKTOR FOOD AND BEVERAGES
TAHUN 2012-2016. Jurnal Riset Manajemen Dan Bisnis (JRMB) Fakultas Ekonomi UNIAT. https://doi.org/10.36226/jrmb.v2i3. 77

PA, M., \& Marbun, D. (2016). Pengaruh Current Ratio Dan Debt To Equity Ratio Terhadap Return On Assets. WIDYAKALA JOURNAL. https://doi.org/10.36262/widyakala. v3i0.21

Parlina, N. D. (2017). Pengaruh Perputaran Modal Kerja Terhadap Profitabilitas Melalui Perputaran Piutang Sebagai Variabel Intervening. Jurnal Inspirasi Bisnis Dan Manajemen. https://doi.org/10.33603/jibm.v1i2.8 67

Putri, Apritika Dwi, Y. T. K. (2020). Pengaruh Perputaran Modal Kerja terhadap Profitabilitas Perusahaan Food and Beverages di BEI Tahun 2013-2017. 1(2), 666-672.

Satriya, I., \& Lestari, P. (2014). PENGARUH PERPUTARAN MODAL KERJA TERHADAP PROFITABILITAS PERUSAHAAN. E-Jurnal Manajemen Universitas Udayana.

Sugiyono. (2015). Metode Penelitian. In Metode Penelitian.

Wirasari, N., \& Sari, M. (2016). PENGARUH PERPUTARAN MODAL KERJA, PERPUTARAN KAS, PERPUTARAN PIUTANG, DAN PERTUMBUHAN KOPERASI TERHADAP PROFITABILITAS. E-Jurnal Akuntansi. 
